
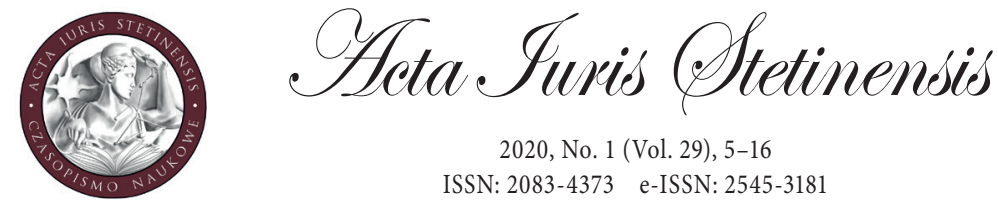

2020, No. 1 (Vol. 29), 5-16

ISSN: 2083-4373 e-ISSN: 2545-3181

DOI: $10.18276 /$ ais.2020.29-01

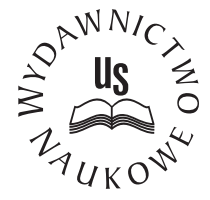

Konrad Drezno

MA

Office of Adrian Szlachciński Attorney at Law, Poland

e-mail: konraddrezno@gmail.com

ORCID ID: 0000-0001-6229-3839

\title{
The issue of taxation with value added tax concerning medical care services provided by speech therapists in light of the interdisciplinary nature of the profession of a speech therapist
}

\begin{abstract}
Due to the lack of a statutory definition and due to the interdisciplinary nature of the profession of a speech therapist, there have been doubts regarding its classification as a medical or paramedical profession. The above is, in fact, of crucial significance from the point of view of tax provisions, since medical care services provided by medical or paramedical facilities, on the condition of fulfilling specific requirements, can enjoy VAT exemption. Unfortunately, there is no definition of medical care in the EU and domestic law, and the requirements necessary to exempt a given service from the discussed tax have not been sufficiently specified. This publication, using a dogmatic method, by hitherto not conducted in literature analysis, was aimed at answering the question of whether medical care services provided by speech therapists are exempt from value added tax. Having achieved the aforementioned objective, the paper explicitly indicates that a speech therapist is a medical profession pursuant to the tax law provisions. The paper also leads to the conclusion that, in principle, medical care services provided by speech therapists are subject to exemption from VAT.
\end{abstract}

Keywords: value added tax, speech therapist, tax law, medical care 


\section{Introduction}

Speech therapy is a young scientific discipline in Poland, the origin of which can be traced back to 1969, the year in which, due to the measures undertaken by Professor Leon Kaczmarek, the Department of Speech Therapy was established at the Maria Curie-Skłodowska University in Lublin. It is the oldest centre of education for speech therapists in Poland, which is currently operating as the Institute of Speech Therapy and Applied Linguistics, managed by Professor Tomasz Woźniak. ${ }^{1}$

In recent years, due to the more frequent developmental problems of children, the aging society and the necessity to provide speech therapy for patients, interest in both education in the scope of speech therapy and speech therapy services has been significantly growing. With regard to the above, the correlation between results in education and speech disorders has been underlined, which also increases the demand for speech therapy services in the scope of preventative measures. ${ }^{2}$

Despite the intensive development of speech therapy and efforts made by the environment, Polish legislation does not at present provide a definition of this profession. The Ministry of Health has made numerous attempts to regulate this profession, and thus, in 2007, a bill on certain medical professions was submitted to the fifth term of the Sejm of the Republic of Poland; however, due to the shortening of this term, this bill did not become the subject of any sessions. ${ }^{3}$ Nevertheless, the aforementioned bill did not define the profession of a speech therapist, but only specified the requirements necessary for performance thereof and omitted the issue of defining speech therapy services. However, it is worth noting that certain regulations stipulating the terms and conditions of employment of a speech therapist at healthcare facilities and educational facilities are included in relevant ordinances of the Minister of Health and the Minister of Education.

The lack of an explicit theoretical and legal definition of the profession of a speech therapist is also significant for determining whether medical care services provided by speech therapists do or do not enjoy value added tax exemption. The aforementioned exemption does cover medical care services provided for preventative

1 Woźniak, T., Edukacja Logopedów w UMCS. Historia-teraźniejszość-przyszłość, "Annales Universitatis Mariae Curie-Sklodowska, sectio N - Educatio Nova" 2016, No. 1, pp. 97-98.

2 Mistal, P., Zależność zaburzeń mowy i osiagnięć szkolnych uczniów klas III szkoły podstawowej, "Logopedia" 2018, Vol. 47-2, pp. 437-450.

3 Sejm Paper no. 1553 of 14 March 2007, www.orka.sejm.gov.pl (accessed 8.02.2020). 
reasons, as well as in order to maintain, save, restore and improve health within the performance of medical professions. ${ }^{4}$

Considering the aforementioned legal status, the aim of the considerations presented herein is to indicate whether services in the scope of medical care provided by speech therapists are subject to value added tax exemption.

The issue discussed herein and achievement of the set objective are of great theoretical and practical importance, in particular, due to the fact that the issue in question is not discussed in the literature.

\section{Sources of exempting medical care services from value added tax}

Considerations regarding taxation of medical care services provided by speech therapists with value added tax should begin with an indication of legal sources providing for an exemption in this scope.

A higher-ranking text including the discussed provisions is Directive 2006/112/ EC, ${ }^{5}$ the provisions of which regulate the possibility of the discussed tax exemption with regard to medical services provided by medical or paramedical entities. Regulations of the aforementioned Directive do not specify the concept of a medical or paramedical profession and use numerous terms of an open character, e.g. the concept of medical care.

It is worth underlining that using this type of vague phrasing is characteristic throughout EU law, which purposefully includes many undefined phrases left to be specified by Member States in compliance with the principle of dualism of the application of Community law. ${ }^{6}$

The above is explicitly confirmed by the CJEU in its judgement of 6 November 2003, which indicated that each Member State is responsible for stipulating the character of medical and paramedical professions under relevant domestic provisions. However, the Court underlined that the aforementioned legislative freedom

4 See Article 43 section 1 point 19 of the Act of 11 March 2004 on value added tax, Dz.U. (Journal of Laws) 2020, item 106, hereinafter: the VAT Act.

5 Council Directive 2006/112/EC of 28 November 2006 on the common system of value added tax (OJ L, No. 347, p. 1), hereinafter: Directive 2006/112/EC.

6 Münnich, M., Problems in interpreting tax exemption of medical services as regulated by the EU VAT Directive and the Polish VAT Act, in: Smoleń, P. (ed.), Selected issues in taxation and tax authorities in Central Europe, Lublin 2016, pp. 113-128. 
of EU States is limited by the teleological interpretation of Directive 2006/112/EC, ${ }^{7}$ conducted by the CJEU.

Therefore, apart from the interpretation of the EU provisions conducted by the CJEU, domestic provisions based on the implementation of Directive 2006/112/EC, i.e. the Act on value added tax and the Act on medical activity, ${ }^{8}$ will be the most important herein.

Nonetheless, it should be underlined that domestic provisions are also not sufficiently specific to dismiss doubts concerning definitions of medical care and the medical or paramedical profession; therefore, specification thereof, apart from the aforementioned judicial decisions of the CJEU, will be provided in judicial decisions of Polish administrative courts and the interpretations of tax authorities.

\section{Speech therapy as a medical or paramedical profession}

As has already been mentioned, the Act on medical activity does not accurately specify who is considered to be a person performing a medical or paramedical profession. In compliance with the provisions thereof, a person performing the said profession is considered to be a person authorised on the grounds of separate provisions to provide healthcare services and a person who acquired professional qualifications to provide healthcare services in a specific scope or in a specific field of medicine. ${ }^{9}$

Considering the fact that legal acts of the statutory rank do not include a legal definition of the profession of a speech therapist, in order to determine whether a specialist in this field can be qualified as a person performing a medical or paramedical profession, one should refer to the regulations included in relevant regulations stipulating, among others, the rules of employing speech therapists at healthcare facilities and educational facilities, as well as conditioning the acquisition of a specialist title in a given field. The analysis of the above provisions leads to the conclusion that among services guaranteed in the scope of outpatient specialist care, ${ }^{10}$ and among services guaranteed in the scope of psychiatric care and

7 Case C-45/01 Christoph-Dornier-Stiftung für Klinische Psychologie v Finanzamt Gießen, ECLI:EU:C:2003:595.

8 Act of 15 April 2011 on medical activity, Dz.U. (Journal of Laws) 2018, item 2190, hereinafter: the Act on medical activity.

9 Article 2 section 1 point 2 of the Act on medical activity.

10 Appendix no. 1 to the Ordinance of the Ministry of Health of 6 November 2013 on services guaranteed in the scope of outpatient specialist care and addiction treatment, Dz.U (Journal of Laws) 2016, item 357. 
addiction treatment, ${ }^{11}$ the Minister of Health enumerated services performed by speech therapists. Simultaneously, in the aforementioned ordinances, the Minister specified the qualifications necessary to hold the position of a speech therapist in facilities providing the services listed above. ${ }^{12}$ It should also be indicated that the specialisation in neuro-speech therapy and speech therapy for the hearing impaired has been placed among healthcare fields in which one can obtain a specialisation. ${ }^{13}$

Taking into account the above regulations, it should be stated that speech therapists have professional qualifications to provide healthcare services in a specific scope or specific field of medicine, which leads to the conclusion that a speech therapist is a medical profession. Nevertheless, doubts can arise as to the fact of employing speech therapists at educational facilities, where they hold the position of speech therapist-teachers. ${ }^{14}$. However, it should be pointed out that speech therapy is a science bordering on various disciplines and combining, among others, educational and medical activities; ${ }^{15}$ thus, the employment of speech therapists at educational facilities as teachers does not exclude qualifying this profession as a medical profession.

The validity of these considerations, despite the lack of a legal act of the statutory rank regulating the profession of a speech therapist, is prejudged by the judgement of the Voivodeship Administrative Court in Szczecin of 8 October 2013, which underlined that the definition of a person performing a medical profession implies that it covers both a person authorised to provide healthcare services on the grounds of separate legal provisions, as well as a person with professional qualifications to provide the aforementioned services, and the legislator's rationalism requires the assumption that while defining the concept of a medical profession, he was aware of the existence of medical professions for which there are no separate statutory provisions. ${ }^{16}$

11 Appendix no. 4 and Appendix no. 6 to the Ordinance of the Ministry of Health of 19 June 2019 on services guaranteed in the scope of psychiatric care and addiction treatment, Dz.U. (Journal of Laws) 2019, item 1285.

12 Appendix no. 1 to the Ordinance of the Ministry of Health of 6 November 2013, op. cit. and $₫ 2$ point 4 of the Ordinance of the Ministry of Health of 19 June 2019, op. cit..

$13 \$ 2$ of the Ordinance of the Ministry of Health of 13 June 2017 on specialisation in areas applied in the healthcare, Dz.U. (Journal of Laws) 2017, item 1217.

$14 \$ 20$ of the Ordinance of the Ministry of National Education of 1 August 2017 on specific qualifications required from teachers, Dz.U. (Journal of Laws) 2017, item 1575.

15 Jastrzębowska, G., in: Gałkowski, T. and Jastrzębowska, G. (eds.), Logopedia - pytania i odpowiedzi: T. 1, Interdyscyplinarne podstawy, Opole 2003, p. 321.

16 Judgement of the Voivodeship Administrative Court in Szczecin of 8 October 2013, I SA/Sz 464/13, Legalis no. 790057. 
The above position of the judicature is also confirmed through numerous individual interpretations of tax provisions, in particular, the Individual Interpretation of the Director of the National Revenue Information of 26 October 2018, indicating that the concept of a person performing a medical profession covers persons performing professions the status of which is statutorily stipulated, as well as professions that do not have such a regulation on the grounds of the binding law. ${ }^{17}$

Among interpretations of tax provisions, from the point of view of qualifying speech therapy as a medical profession, the most important is the Individual Interpretation of the Director of the Treasury Office in Łódź of 21 August 2013, in which the tax authority unequivocally stated that a speech therapist is a person performing a medical profession pursuant to the Act on medical activity. ${ }^{18}$ Furthermore, the tax authority conducted a short analysis of the above issue by stating that a speech therapist has professional qualifications to provide healthcare services and the profession of a speech therapist has been enumerated along with other medical professions in a number of healthcare-related provisions, by reference to provisions concerning acquiring the title of a specialist in the area of neuro-speech therapy or speech therapy for the hearing impaired. Nevertheless, it is worth noting that in the interpretation in question, the authority made a fundamental mistake by stating that the title of a speech therapist can only be used by a person who graduated from higher education or postgraduate education in this scope, since this title, due to the lack of statutory regulation of the profession of a speech therapist, is not legally protected; however, this mistake has no real impact on the legibility of solutions adopted by the authority.

It should be underlined that even before the aforementioned position, tax authorities considered the profession of a speech therapist as a medical profession; however, the analysis conducted by them was not exhaustive and left certain doubts. The Individual Interpretation of the Director of the Treasury Office in Poznan of 13 July 2012 should be indicated as an example in which the authority considered speech therapy as a medical profession; however, it wrongly indicates only what is involved in the performance of the profession of a speech therapist and does not elaborate on the most important issue, namely, having professional qualifications. ${ }^{19}$

Currently, the position of tax authorities is unequivocal. Tax authorities consider the profession of a speech therapist as a medical profession. This is also confirmed

17 Individual Interpretation of the Director of the National Revenue Information of 26 October 2018, 0114-KDIP1-3.4012.535.2018.1.MK, Legalis.

18 Individual Interpretation of the Director of the Treasury Office in Łódź of 21 August 2013, IPTPP1/443-413/13-4/MH, Legalis.

19 Individual Interpretation of the Director of the Treasury Office in Poznan of 13 July 2012, ILPP2/443-609/12-3/AK, Legalis. 
by the newest interpretations within this scope, i.e. the Individual Interpretation of the Director of the National Revenue Information of 8 January 2020, ${ }^{20}$ and the Individual Interpretation of the Director of the National Revenue Information of 17 January $2020 .^{21}$

Domestic judicial and administrative decisions concerning qualification of the profession of a speech therapist as a medical or paramedical profession are confirmed by the judgements of the CJEU concerning value added tax.

In the first place, one should refer to the judgement of the CJEU of 6 November 2003, in which the Court considered services performed by non-doctors, such as psychotherapeutic services performed by psychologists, as providing medical care services within the performance of medical and paramedical services. ${ }^{22}$ Therefore, the Court of Justice indicated that a psychologist is one of the medical or paramedical professions and, taking into account numerous similarities in the scope of education, the field of science and methodology of the work of psychologists and speech therapists, it should be stated that a speech therapist should also be considered as one of such professions.

With reference to the above, it is worth underlining that in the currently binding Act on value added tax, in the context of tax exemption concerning medical care services, the profession of a psychologist was directly enumerated, ${ }^{23}$ which is not the case for the profession of a speech therapist. It is worth noting that the amendment implementing the exemption of medical care services was introduced with the Act of 29 October 2010, which was already after the announcement of the aforementioned judicial decision of the CJEU.

To summarise the analysis of legal provisions and judicial and administrative decisions conducted in this part, it can be concluded that due to significant problems concerning identification of entities subject to the discussed exemption of value added tax, the act regulating this levy requires an amendment consisting in the extension of the catalogue of professions considered as medical or paramedical. For taxpayers, the above amendment would undoubtedly fundamentally facilitate the qualification of services they offer, of course, with a preservation of the currently justly applied open catalogue of entities that can be considered as medical or paramedical professions.

20 Individual Interpretation of the Director of the National Revenue Information of 8 January 2020, 0112-KDIL4.4012.535.2019.2.MB, Legalis.

21 Individual Interpretation of the Director of the National Revenue Information of 17 January 2020, 0112-KDIL2-2.4012.574.2019.4.MŁ, Legalis.

22 Case C-45/01, op. cit.

23 See Article 43 section 1 point $19 \mathrm{~d}$ of the VAT Act. 


\section{Medical care services provided by speech therapists subject to the exemption of value added tax}

Taking into account the aforementioned reflections, the conclusion of which consists in the statement that a speech therapist is a medical profession pursuant to tax provisions and provisions of the Act on medical activity, it should be stated that the vast majority of services offered by speech therapists will comprise medical care services. At this point, it is worth underlining that both the EU and domestic provisions do not provide a definition of legal medical care, i.e. the key concept in the analysis of the discussed issue.

Decoding the semantic scope of medical care on the grounds of the VAT Directive was specified by the CJEU in the judgement of 8 June 2006, in which it indicated that the concept of medical care refers to services that are provided for the purposes of diagnosis, care and, if possible, treatment of illnesses and health disorders. ${ }^{24}$ The above definition, despite being quite broad, is undoubtedly correct, as it allows qualifying services provided both for the benefit of ill persons and those with health disorders, as well as healthy persons requiring specialist care or diagnosis, as medical care, which is especially important in the case of speech therapy services, often provided for the benefit of healthy children and adults; whereas, the aforementioned services in the scope of diagnosis or specialist care are considered as being aimed at prevention. Moreover, the fact that in order to deem a service as medical care, the service does not have to be aimed at treating illnesses or health disorders is significant in the above definition, since services provided for ill persons or those with disorders, in the case of whom speech therapy cannot result in improvement of their health and is only aimed at the maintenance of a given condition or facilitating communication of those persons with the environment, can also be qualified as medical care.

The Polish Act on value added tax, in compliance with the judicial decisions of the CJEU, indicates that the premise for exempting a medical care service constitutes the fact that it is aimed at prevention, as well as maintaining, saving, restoring and improving health. ${ }^{25}$ Thus, a contrario medical care services provided by a medical or paramedical entity which do not serve the above objectives will not be covered by tax exemption. Therefore, not all services provided by a speech therapist, even if they constitute services in the scope of medical care, will be covered by the value added tax exemption.

24 Case C-106/05 L.u.P. GmbH v Finanzamt Bochum-Mitte, ECLI:EU:C:2006:380.

25 Article 43 section 1 point 19 of the VAT Act. 
Once again, judicial decisions of the CJEU, as well as judicial decisions of administrative courts and interpretations of tax authorities, will be extremely helpful to specify objectives that should be served by medical care services in order to be covered by the discussed exemption.

In the first place, the judgement of the CJEU of 20 November 2003 should be quoted, in which it was stated that the aim of a given service determines whether the given service should be exempt from value added tax. The aim of the medical care service provided by speech therapists, which comprises the discussed tax exemption, should be, in fact, prevention, as well as maintaining, saving, restoring and improving health. However, it should be stated that this aim does not have to be achieved. Therefore, it is sufficient when activities undertaken within such a service serve the activities enumerated in the tax law and do not lead to a specific result. ${ }^{26}$

The above position was adopted in judicial decisions of Polish administrative courts, where, as an example, the judgement of the Voivodeship Administrative Court in Kraków of 6 October $2016^{27}$ and the judgement of the Voivodeship Administrative Court in Warszawa of 24 May $2016^{28}$ can be enumerated, and thus, these judicial decisions should be considered as grounded direction of jurisdiction.

Nevertheless, with regard to the above, the most important is the judgement of the Voivodeship Administrative Court in Poznań of 18 January 2012, in which minimal conditions that must be met by a medical care service in order to enjoy tthe discussed exemption were specified. In the above judicial decision, the court notices that medical care services are required to at least ensure the possibility of assessing a patient's health in order to make a correct diagnosis and propose a proper therapeutic procedure adjusted to the requirements of the specific person. ${ }^{29}$

The referred judicial decisions correspond with the position of tax authorities expressed in, among others, the Individual Interpretation of the Director of the National Revenue Information of 8 January $2020,{ }^{30}$ and the Individual Interpretation

26 Case C-212/01 Margarande Unterpertinger v Pensionsversicherungsanstalt der Arbeiter, ECLI:EU:C:2003:625.

27 Judgement of the Voivodeship Administrative Court in Kraków of 6 October 2016, I SA/Kr 965/16, Legalis no. 1543086.

28 Judgement of the Voivodeship Administrative Court in Warszawa of 24 May 2016, III SA/Wa 1595/15, Legalis no. 1555618.

29 Judgement of the Voivodeship Administrative Court in Poznań of 18 January 2012, I SA/Po 767/11, Legalis no. 486648.

30 Individual Interpretation of the Director of the National Revenue Information of 8 January 2020, op. cit. 
of the Director of the National Revenue Information of 17 January $2020 .{ }^{31}$ In the former, with reference to previous positions, the tax authority extends the catalogue of entities exempt from tax to medical care services offered by speech therapists with services related to hearing tests performed by a speech therapist. Furthermore, the tax authority indicates that the exemption also covers diagnosis and speech therapy, since, as in the case of a hearing test, they are aimed at prevention, as well as maintaining, saving, restoring and improving health. In the latter, the authority states that the turnover tax exemption covers therapy and consultation in the scope of clinical speech therapy.

The above interpretations confirm the hitherto position of tax authorities, including that included in the Interpretation of the Treasury Office in Warszawa of 10 March 2011, in which the authority, for the first time, stated that the services provided by a speech therapist in the scope of diagnosis and therapy of communication disorders at various development stages and various spheres of educational, social and professional activity are subject to value added tax exemption. ${ }^{32}$

Finally, it is worth underlining that in order for medical care services to be able to enjoy the discussed exemption, such services can also be provided remotely via communication means, which is confirmed through numerous judicial decisions, including the judgement of the Voivodeship Administrative Court in Poznan of 18 January 2012, in which the court indicated that medical care services provided via the Internet cannot be excluded. ${ }^{33}$

The above position expressed by the Voivodeship Administrative Court is confirmed and extended by the Individual Interpretation of the Director of the National Revenue Information of 21 January 2020, referring to the services provided by a psychologist via the Internet. In the above interpretation, the authority explicitly indicated that application of the tax exemption with regard to the provided services cannot be decided by the type of communication means through which the given service is provided, since the communication means constitute the sole tool for providing services. ${ }^{34}$

31 Individual Interpretation of the Director of the National Revenue Information of 17 January 2020, op. cit.

32 Individual Interpretation of the Treasury Office in Warszawa of 10 March 2011, IPPP1-443138/11-2/PR, Legalis.

33 Judgement of the Voivodeship Administrative Court in Poznań of 18 January 2012, op. cit.

34 Individual Interpretation of the Director of the National Revenue Information of 21 January 2020, 0114-KDIP4-2.4012.16.2019.1.WH, Legalis. 


\section{Medical care services provided by speech therapists not subject to the value added tax exemption}

As has already been mentioned, not all medical care services are subject to value added tax exemption. The above exemption does not cover services not aimed at prevention, as well as maintaining, saving, restoring and improving health, and not fulfilling the conditions stipulated in the aforementioned judicial decisions and interpretations.

The CJEU, in the judgement of 20 November 2003, stated that if the context in which a given medical service is provided is aimed at giving advice before making a decision related to legal consequences, the exemption does not apply to this service, unless such a service is mainly aimed at patients' healthcare, e.g. certificates concerning the ability to travel. As an example of services not covered by the exemption, the Court indicated issuing certificates on one's health necessary for purposes such as receiving a social security pension and medical tests aimed at drawing up a report on the responsibility and size of the damage for persons intending to claim injury to the individual or to file a lawsuit. Thus, the above services provided by speech therapists will not enjoy the value added tax exemption. ${ }^{35}$

With reference to the above, it is worth quoting the judgement of the Supreme Administrative Court of 7 February 2018, where a thesis was presented that treatments and examinations executed for a purpose other than human healthcare cannot enjoy the discussed exemption, and as an example, activities related to providing an opinion of legal significance were indicated. ${ }^{36}$ Therefore, the judgment fully confirms the position of the CJEU.

\section{Conclusion}

To conclude the presented considerations, it should be stated that, putting any doubts of representatives of the science of speech therapy aside, a speech therapist is a medical profession from the point of view of the Act on value added tax and the Act on medical activity. This position is unequivocally confirmed by the judicial decisions of the CJEU and domestic courts, as well as the interpretations of tax authorities.

35 Case C-307/01 Peter d'Ambrumenil and Dispute Resolution Services Ltd v Commissioners of Customs \& Excise, ECLI:EU:C:2003:627.

36 Judgement of the Supreme Administrative Court of 7 February 2018, I FSK 866/16, Legalis no. 1740480 . 
Another significant issue constitutes qualification of a given service provided by a speech therapist as medical care. In compliance with the judicial decisions of the Court of Justice, medical care means activities that are aimed at a diagnosis, care and, as far as possible, treatment of illnesses or health disorders. Thus, if the services provided by a speech therapist meet the above criterion, they are considered as medical care.

However, it should be indicated that a given service can be qualified as exempt from tax provided that it is aimed at prevention, as well as maintaining, saving, restoring and improving health. The above criteria have been specified by the judicial decisions and interpretations; thus, it is worth taking into account the position of the judicature established in this scope.

In compliance with the above, not all services provided by speech therapists, even when they constitute medical care, will be subject to the turnover tax exemption. Therefore, to conclude, it should be stated that qualifying a given service provided by speech therapists as exempt from taxation with the aforementioned tax requires an analysis each time.

\section{References}

Jastrzębowska, G., in: Galkowski, T. and Jastrzębowska, G. (eds.), Logopedia - pytania i odpowiedzi: T. 1, Interdyscyplinarne podstawy, Opole 2003.

Mistal, P., Zależność zaburzeń mowy i osiagnięć szkolnych uczniów klas III szkoły podstawowej, "Logopedia" 2018, Vol. 47-2.

Münnich, M., Problems in interpreting tax exemption of medical services as regulated by the EU VAT Direcitive and the Polish VAT Act, in: Smolen', P. (ed.), Selected issues in taxation and tax authorities in Central Europe, Lublin 2016.

Woźniak, T., Edukacja Logopedów w UMCS. Historia-teraźniejszość-przyszłość, “Annales Universitatis Mariae Curie-Sklodowska, sectio N - Educatio Nova” 2016, No. 1.

\section{CITATION}

DREZNO, K., The issue of taxation with value added tax concerning medical care services provided by speech therapists in light of the interdisciplinary nature of the profession of a speech therapist, "Acta Iuris Stetinensis" 2020, No. 1 (Vol. 29), 5-16, DOI: 10.18276/ais.2020.29-01. 